\title{
BMPR1B Gene
}

National Cancer Institute

\section{Source}

National Cancer Institute. BMPR1B Gene. NCI Thesaurus. Code C73559.

This gene is involved in the mediation of signal transduction. 